\title{
Re-thinking the Role of Rural Tourism. Potentials for a Sustainable Transborder Tourism in the Area Bulgaria- Greece
}

\author{
Rouska Krasteva ${ }^{1}$, Teodora Kiryakova-Dineva ${ }^{2}$
}

\begin{abstract}
:
The paper aims to analyze the transborder area between South-West Bulgaria and Northern Greece through the lenses of sustainable rural tourism. The research evaluates the potentials for rural tourism by exploring

the competitiveness of the chosen borderland. The applied qualitative analysis uses the complex aggregate indicator of competitiveness which is comprised of twelve criteria. The final aim of research is to emphasize the role of rural tourism so to rethink the possibilities of a common transborder strategy for sustainable rural tourism. The interesting and unique aspect of the study lays in its holistic approach and its deductive character.
\end{abstract}

Keywords: rural tourism, transborder area Bulgaria-Greece, competitiveness analysis and evaluation, sustainability

\section{Introduction}

Social and cultural constructions of space and location are often marked through the concept of border. The role of borders, particularly the interregional and international ones can be affirmed by the intensified contacts of border communities and strengthened international cooperation. Having a complex nature and at the same time being made up of a wide set of social and intercultural ties, the transborder area generates a new paradigm of relationships in the sphere of tourism. As multidimensional phenomena, travel, hospitality and leisure do not stand away, but intensively profit from the potentials of international transborder tourism and even achieve a more sustainable feature in their profiling. The interconnections in the scope of tourism activities can further foster sustainability effects at various levels of tourism experience (natural and anthropogenic tourism resources, management of leisure, intellectual capital), on the one hand, and added values for economy, society and culture, on the other. This assumption does not present a scientific novelty, but the importance of the issues proposed can be confirmed on reference to almost every other border area, where such relations bear the same attributive character.

The subject of this research is namely the specific border line between SouthWest Bulgaria and Northern Greece and it is seen from the perspective of rural tourism. The proposed discussion is limited to the scope of rural tourism, because of the similarity of both regions where rural settings prevail. The applied qualitative analysis uses the complex aggregate indicator of competitiveness which comprises twelve criteria. The aim of the present study is to confirm the merits of a common cross-border strategy 
for development of rural tourism in that region. The study furthers awareness of the sustainability effects between various levels of tourism activities (authenticity, management of leisure) and added values for economy, society and culture (such as exploration of local and national cultural narratives and metaphorical undercurrents in folklore [13]). The interesting and unique side of the study is its approach and its affirmative function, namely to acknowledge the role of rural tourism and accept its potential not as a panacea (Briedenhann and Wickens, 2004) [2] but as a tool for sustainable development in a border area. This study overviews rural tourism as an alternative (soft) kind of sustainable tourism, which plays an important role for the development of rural areas in the district of Blagoevgrad in south-west Bulgaria and in regional units Drama and Serres in northern Greece. Another aspect of the study is to explore it as a type of tourism which meets the needs of the modern man for a short getaway (a break from the daily rhythm of urban life [10]), for coacting with nature, getting to know the specific cultural characteristics of each area, for entertainment and relaxation.

\section{Rural Tourism and its Role of a Sustainable Transborder Tourism}

Rural tourism as a separate sub-sector of the tourism industry is growing and constantly changing. Tourism professionals relate its significance largely to "natural, social and community values" [16]. The ideas of "rusticity and authenticity" [3] or the challenges of "strategic, administrative and personal features" [18] or of image representations $[12,20,11]$ are often discussed as a source of innovative solutions. More precisely, many additional terms for complexity and development planning [4, 8, 19, 24] and through different policies $[28,23]$ are becoming an increasingly important topic of public debate, i.e. INTERREG, EQUAL, CIP, URBAN, ERDF, LEADER, COESIMA, GENDERI [28]. In addition to its economic worth, the role of rural tourism continues to be conceived as a means for successful managerial device [27, 26, $9,4,22]$.

Additionally, new market trends and experiences of farmers in the implementation of projects for the development of rural tourism, business initiatives and investments by local and state authorities, European and international institutions contribute to the more dynamic nature of rural tourism compared with the initial stage of development in Greece in the early 80-ies [10, 15] and in Bulgaria, respectively, in the early 90 -ies of the last century.

There is no consensus on the scientific definition of rural tourism as the views of individual researchers are influenced in varying degrees by their cultural and national differences. With regards to the chosen area it is worth to mention the definition of the Hellenic Organization of Tourism (1983) which states that "rural tourism is a touristic activity that is developed in non urban areas basically from the employees of agriculture, in small family or partnership enterprises, with the aim to achieve supplemental income for the local residents offering accommodation, food of local production and products of similar activities" [15]. Mihailidis [16] relates rural tourism to the type of tourism which develops basically in rural areas and is reliant on the utilization of natural, cultural and human local recourses, gratifies special personal needs of modern people and aims at 
the restraint and return of the local population to the homeland and at ensuring supplemental income and at the rise of living and cultural standard.

Initially, the functions of rural tourism were connected mostly to urban travelers whose basic motive was to stay in a village in order to be very close to nature [10, 21]. The quality of service in rural tourism is more sophisticated these days, but the aim of village visitors remains the same: to avoid urban noise and polluted urban environment. From a contemporary point of view, enlarging the limits of national rural tourism leads to sustainability on a transnational level.

Taking into consideration all of the above and applying it for the purposes of this paper, a new scope can be offered which in some way expands the concept of the term rural tourism and suggests the use of the concept of transborder rural tourism.

Transborder rural tourism is a specific type of alternative tourism that takes place in transborder rural communities [20, 25, 1], has huge potentials as regards identities and traditions peculiar to the rural way of life and successfully combines the use of existing natural and cultural resources, including cultural and historical heritage, agricultural activities, rest and recreation in a way that satisfies the needs of tourists and contributes to the economic development of border regions [23, 21, 4, 19].

\section{Methodology and Analysis}

The development of transborder rural tourism requires the existence of certain preconditions. In this paper these preconditions will be examined, in order to see which the opportunities for cross-border cooperation in the area of rural tourism in south-west Bulgaria and northern Greece are. The regions that will be taken under consideration are the peripheral units Drama and Serres in Greece and the district of Blagoevgrad in Bulgaria.

The choice of these particular regions is predicated on their similar geographic positions along the rivers Struma (Strymonas) and Mesta (Nestos) and on their common historical background and economic development.

Based on the score cards used and completed by experts in the tourism area and complementary to the data from the questionnaires presented to the representatives of the tourism industry and tourists, separate assessments could be made about the competitiveness of the three regions that develop rural tourism as well as about their opportunities for transborder cooperation. The experts (30 experts -10 from each one of the three regions) evaluated the competitiveness of each region. The estimation was conducted on the basis of twelve criteria and several indicators an a scale of 1 to 10 points.

Table 1. Criteria for analysis and evaluation of the destinations of rural tourism

\begin{tabular}{|l|l|}
\hline & \multicolumn{1}{|c|}{ Criteria } \\
\hline 1. & Tourism infrastructure \\
\hline 2. & Tourism superstructure \\
\hline 3. & Nomenclature and deversification of the tourism product promoted in the area \\
\hline 4. & Sustainable image of the region as a destination for rural tourism \\
\hline
\end{tabular}




\begin{tabular}{|l|l|}
\hline 5. & Quality of stay (quality of the tourism product) \\
\hline 6. & Price of tourism product \\
\hline 7. & Competency of natural tourism resources \\
\hline 8. & Competency of anthropogenic tourism resources \\
\hline 9. & Conditions and development of intellectual capital \\
\hline 10. & $\begin{array}{l}\text { Support on the side of public administration for the development of rural tourism in } \\
\text { the regions }\end{array}$ \\
\hline 11. & Development of the supply network \\
\hline 12. & Ensuring the tourism development with strategic and planning documents \\
\hline
\end{tabular}

The criteria, elaborated by Ribov (1997) were modified and completed so as to show the objective reality in the examined regions.

The form for calculating the complex aggregate indicator of competitiveness is the following:

$$
\begin{aligned}
C I C= & \left(W_{1} I_{T I}+W_{2} I_{T S}+W_{3} I_{N A}+W_{4} I_{S I M}+W_{5} I_{Q}+W_{6} I_{P}+W_{7} I_{A N R}+W_{8} I_{A A R}+\right. \\
& \left.+W_{9} I_{S D I C}+W_{10} I_{S P A}+W_{11} I_{S C D}+W_{12} I_{A S P D}\right)
\end{aligned}
$$

where: CIC - is the complex aggregate indicator of competitiveness for the regions that develop rural tourism, W - is the criteria weight, $\boldsymbol{I}_{\boldsymbol{T I}}$ - is the complex group indicator for infrastructure of the evaluated destination, $\boldsymbol{I}_{T S}-$ is the complex group indicator for tourism superstructure of the evaluated destination, $\boldsymbol{I}_{\boldsymbol{N A}}$-is the complex group indicator for nomenclature and assortment of the tourism product promoted in the evaluated destination, $\boldsymbol{I}_{\boldsymbol{S I M}}$-is the complex group indicator for the sustainable image of the evaluated destination, $\boldsymbol{I}_{\boldsymbol{Q}}-$ is the complex group indicator for the quality of stay in the evaluated destination, $\boldsymbol{I}_{\boldsymbol{P}}$ - is the complex group indicator for the price of the tourism product of the evaluated destination, $\boldsymbol{I}_{\boldsymbol{A} \boldsymbol{N} \boldsymbol{R}}-$ is the complex group indicator for the competency of natural tourism resources of the evaluated destination, $\boldsymbol{I}_{\boldsymbol{A} \boldsymbol{A} \boldsymbol{R}}-$ is the complex group indicator for the competency of anthropogenic tourism resources of the evaluated destination, $\boldsymbol{I}_{\boldsymbol{S D I C}}$-is the complex group indicator for the conditions and developments of intellectual capital in the evaluated destination, $\boldsymbol{I}_{\boldsymbol{S P A}}$-is the complex group indicator for the support from the side of public administration for the development of the evaluated destination, $\boldsymbol{I}_{\boldsymbol{S} \boldsymbol{C} \boldsymbol{D}}$-is the complex group indicator for the development of the supply net of the evaluated destination and $\boldsymbol{I}_{\boldsymbol{A S P D}}$ - is the complex group indicator for the assurance of tourism development with strategic and planning documents in the evaluated destination. For estimating the relative aggregate coefficient for competitiveness, which aims to compare the competitiveness of the three regions, the form that can be used is the following:

$$
R_{c i c}=\frac{C I C_{e}}{C I C_{b}},
$$


where: $R_{C I C}$ - is the relative aggregate coefficient for competitiveness of the evaluated destination, $\mathrm{CIC}_{e}$ - is the complex aggregate indicator of competitiveness of the evaluated destination and $C_{b}$ - is the complex aggregate indicator of competitiveness of the base region for rural tourism, with which is the comparison done.

When the value of the relative aggregate coefficient for competitiveness is higher than one $\left(R_{C I C}>1\right)$, then the evaluated region for rural tourism is more-competitive in comparison with the base region. And the opposite, when the relative aggregate coefficient for competitiveness is lower than one $\left(R_{C I C}<1\right)$, then the evaluated region is less-competitive than the base region for rural tourism. Figure 1 presents the absolute values of aggregate coefficients for competitiveness of the examined regions developing rural tourism.

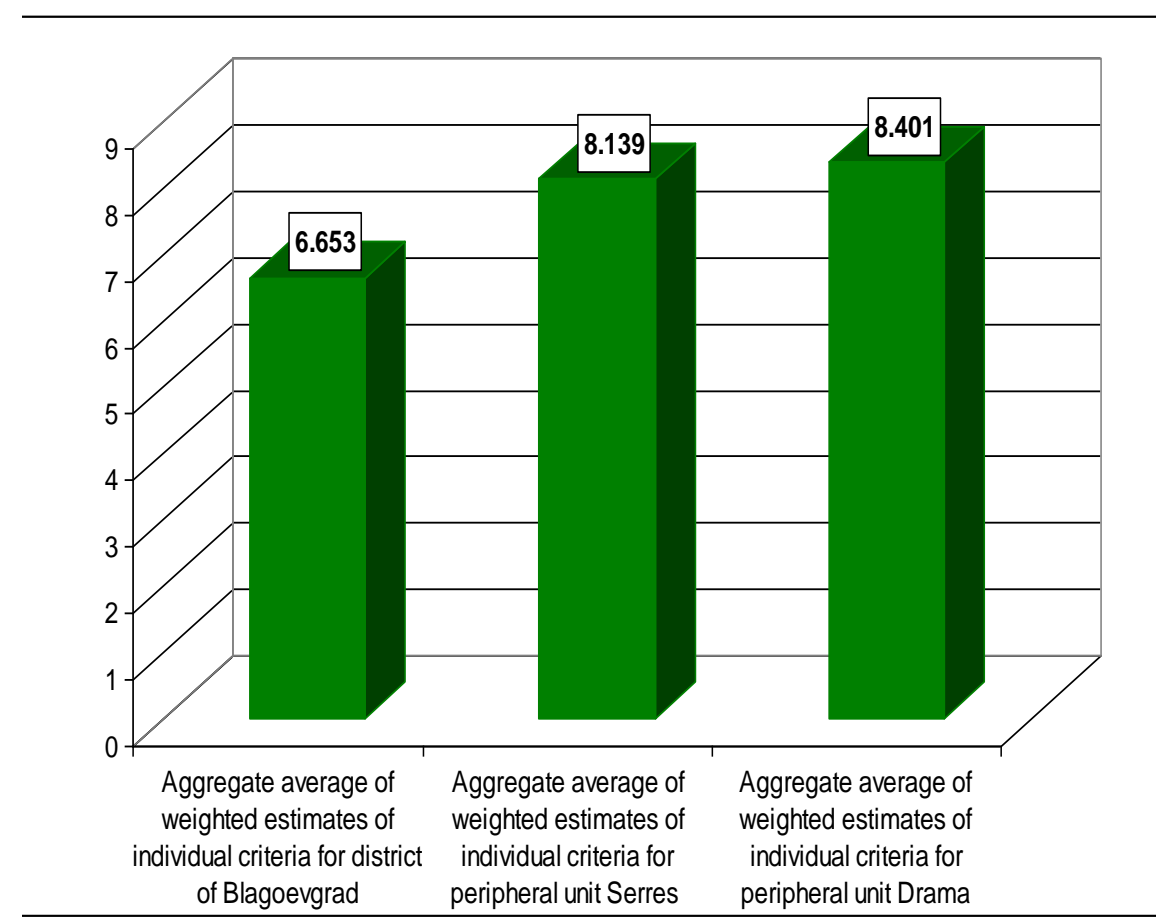

Figure 1. Absolute values of aggregate coefficients for competitiveness

Source: own research of $\mathrm{R}$. Krasteva (2014)

The results from the calculation of the relative values of aggregate coefficients for competitiveness of the evaluated destinations are presented in tabular form in Table 3 , Table 4 and Table 5. 
Table 2 Relative values of aggregate coefficient for competitiveness of district Blagoevgrad in comparison with peripheral units Serres and Drama

\begin{tabular}{|c|l|l|}
\hline \multicolumn{2}{|c|}{ Blagoevgrad } & \multicolumn{2}{|c|}{ Percentage } \\
\hline $\begin{array}{c}\text { Values } \\
\text { Aggregate average of weighted estimates of } \\
\text { individual criteria for district of Blagoevgrad }\end{array}$ & 6,653 & \\
\hline $\begin{array}{l}\text { Relative aggregate coefficient for } \\
\text { competitiveness of the district of Blagoevgrad in } \\
\text { comparison with peripheral unit Serres }\end{array}$ & 0.817422288 & $81.74 \%$ \\
\hline $\begin{array}{l}\text { Relative aggregate coefficient for } \\
\text { competitiveness of the district of Blagoevgrad in } \\
\text { comparison with peripheral unit Drama }\end{array}$ & 0.791929532 & \\
& & \\
\hline
\end{tabular}

Source: own research of R. Krasteva (2014)

Table 3 Relative values of aggregate coefficient for competitiveness of peripheral unit Serres in comparison with district Blagoevgrad and peripheral unit Drama

\begin{tabular}{|c|c|c|}
\hline \multicolumn{3}{|l|}{ Serres } \\
\hline & Absolute Values & Percentage \\
\hline $\begin{array}{l}\text { Aggregate average of weighted } \\
\text { estimates of individual criteria for peripheral } \\
\text { unit Serres }\end{array}$ & 8.139 & \\
\hline $\begin{array}{l}\text { Relative aggregate coefficient for } \\
\text { competitiveness of peripheral unit Serres in } \\
\text { comparison with the district of Blagoevgrad }\end{array}$ & 1.223357884 & $122.34 \%$ \\
\hline $\begin{array}{l}\text { Relative aggregate coefficient for } \\
\text { competitiveness of peripheral unit Serres in } \\
\text { comparison with peripheral unit Drama }\end{array}$ & 0.968813237 & $96.88 \%$ \\
\hline
\end{tabular}

Source: own research of $\mathrm{R}$. Krasteva (2014) 
Table 4 Relative values of aggregate coefficient for competitiveness of peripheral unit Drama in comparison with district Blagoevgrad and peripheral unit Serres

\begin{tabular}{|c|c|c|}
\hline \multicolumn{1}{|c|}{ Drama } & Absolute Values & Percentage \\
\hline $\begin{array}{c}\text { Aggregate average of weighted } \\
\text { estimates of individual criteria for peripheral } \\
\text { unit Drama }\end{array}$ & 8.401 & \\
\hline $\begin{array}{c}\text { Relative aggregate coefficient for } \\
\text { competitiveness of peripheral unit Drama in } \\
\text { comparison with the district of Blagoevgrad }\end{array}$ & 1.26273861 & $126.27 \%$ \\
\hline $\begin{array}{c}\text { Relative aggregate coefficient for } \\
\text { competitiveness of peripheral unit Drama in } \\
\text { comparison with peripheral unit Serres }\end{array}$ & 1.03219069 & $103.22 \%$ \\
\hline
\end{tabular}

Source: own research of $\mathrm{R}$. Krasteva (2014)

\section{Results and discussion}

In summarizing the data of the analysis and considering the additional graphical/ tabular representations, some main assessments of the competitiveness in the regions under exploration can be emphasized. The main results can be listed as follows:

$\checkmark \quad$ The peripheral unit Drama has the highest absolute value of aggregate coefficients for competitiveness followed by the peripheral unit of Serres and the district of Blagoevgrad, which corresponds to the degree of development of rural tourism in these regions.

$\checkmark \quad$ The profile of Blagoevgrad as a region for the development of rural tourism follows the profiles of the peripheral units Serres and Drama.

The development of sustainable rural tourism along the Bulgarian border can be considered with a time period of one or two decades. This could be explained by the later start of the development of rural tourism in Bulgaria as a whole (1994-1995) contrary to the picture in Greece (earlier start in 1982-1983). The transition to a more competitive sustainable transborder rural tourism has to take into account this correlation and additionally to take into account some other aspects, such as:

A "Sustainable image of the region as a destination for a transborder rural tourism" can be asserted as leading criterion for both regions on the borderline. Interesting features are to be expected in the district of Blagoevgrad whereas the region is characterized by unexploited potentials for rural tourism.

New effects of synergy are to be expected due to the new line of common transborder proactive measures which would be possible because of the more 
intensive marketing activity for promoting the resorts of Bansko and Kovatchevitsa.

The proposed strategic aim is to be implemented in order to increase the competitiveness through coordination of tourism supply in the border area regions. Small steps to foster their implementation can be additionally made through other activities, such as:

$\checkmark \quad$ Achieving of coordinated joint actions for transborder tourism activities;

$\checkmark \quad$ Creating and offering of joint tourism products;

$\checkmark \quad$ Improving the organization and quality of tourism products;

$\checkmark \quad$ Increasing the number of visits in the transborder areas and prolonging the tourist season;

$\checkmark \quad$ Improving the advertising and communication policy of the transborder regions; Improving the distribution policy of the border regions, offering rural tourism;

Supporting the joint efforts for economic development, employment and sustainability.

The potential for increasing the competitiveness of rural tourism in the destinations of Blagoevgrad, Serres and Drama shows the need of the implementation of a set of actions, some of which require changes in the approach to the development of rural tourism of tourism approach, a more efficient work organization and establishment of new partnerships. Other possible actions, however, can be achieved through investments in technical facilities, equipment, or human resources.

The possible risks for the realization of the potential for increasing the competitiveness of transborder rural tourism in the destinations of Blagoevgrad, Serres and Drama are mainly connected with the lack of sufficient awareness among the local communities. There is unsatisfactory knowledge about joint activities, lack of satisfactory administrative capacity in the municipal administrations and local firms (knowledge of Greek and English, experience in project related networking, etc.) and lack of financial resources [10].

\section{Conclusion}

The present paper dealt with the problem of enlarging the connection between rural tourism and sustainability in borderland. The need of re-thinking the role of rural tourism was discussed where a further awareness raising of the sustainability effects between various levels of tourism experience is to be expected. Natural and anthropogenic tourism resources, leisure management and sources of intellectual capital are seen as possible facilitators in that direction. The analysis and evaluation of the competitiveness of the regions in Bulgaria and Greece provided a framework on the basis of which a future strategy will give the opportunity for common initiatives for better sustainable transborder tourism on the one hand, and for a better rural tourism on a transborder level, on the other. Various added values for economy, society and culture can be further expected. Last but not least, it can be concluded that the above mentioned issues contained to a certain degree reflections of the main problems identified during the analysis and evaluation stage of the research. 


\section{References}

Benovska-Sabkova, M., \& Nedin, I. (2016.). Secular Mood, Community Consensus The Identity of the Bulgarian Muslims in Zlatograd. Migration - Networks - Skills, 67-84.

Briedenhann, J., \& Wickens, E. (2005). Combining qualitative and quantitative methods in evaluation-related rural tourism development research. Methods in Development Research, 85-92.

Bouchon, F. \& Rawat, K. (2016). Rural areas of ASEAN and Tourism Services, a Field for Innovative solutions. Social and Behavioral Sciences 224 (2016), pp. $44-51$.

Dimitrov, P. M., Stankova, M. Z., Vasenska, I., \& Uzunova, D. (2017). Increasing attractiveness and image recognition of Bulgaria as a tourism destination. Tourism \& Management Studies, 13(3), 39-47. doi:10.18089/tms.2017.13305

Dolzblasz, S. (2017). From divided to shared spaces: Transborder tourism in the Polish-Czech borderlands. Tourism and Geopolitics: Issues and Concepts from Central and Eastern Europe, 163-177.

Fedorov, M., \& Korneevets, V. (2009). Trans-Border Regions in the System of the Regional Hierarchy: The Systemic Approach. Baltic Region, (2). doi:10.5922/2079-8555-2009-2-3

Ilbery, B. (1995). Critical issues in tourism: A geographical perspective. Applied Geography, 15(1), 90.

Ilbery. B., \& Saxena, G. (2011). Integrated rural tourism in the English-Welsh cross-border region: An analysis of strategic, administrative and personal challenges. Regional Studies. 45 (8), 1139-1155.

Kiryakova-Dineva, T., Hadzhipetrova-Lachova, M., \& Chankova, Y. (2017). Intercultural Dialogue For Education In The Mediterranean Region. EDULEARN17 Proceedings. doi:10.21125/edulearn.2017.1845

Krasteva, R. (2014). Selski turizam. Mezhduregionalni osobenosti. Sofia: Avangard Prima. [in Bulgarian.

Кръстева, Р. (2014). Селски туризъм. Междурегионални особености. София: АвангарА Прима.]

Kyurova, V., \& Yaneva, D. (2017). Research On The Impact Of The Corporate Image On The Competitiveness Of Interior Design Enterprises. CBU International Conference Proceedings, 5, 495. doi:10.12955/cbup.v5.973

Kyurova, V. (2013). The image as a source of competitive advantage in hotel business. Entrepreneurship, 1(12), 70-76.

Levunlieva, M., Kiryakova-Dineva, T., \& Krasteva, R. (2017). Information Availability And The Process Of Academic Internationalization (On The Example Of South-West University "Neofit Rilski" Blagoevgrad). EDULEARN17 Proceedings. doi:10.21125/edulearn.2017.1067

Levunlieva. (2017). Metaphorical Undercurrents in Bulgarian Folk Songs. Analele Universităţii din Craiova. Seria Ştiințe Filologice. Lingvistică, (1-2), 287-297.

Logothetis, M. (1988). Rural Tourism - an alternative solution. Athens.

Mihailidis, D. (2009). "Rural Tourism concerns negatively and Philoxenia". Tourism and People. Sept.-Okt. 2009. Vol 90. 19-26.

Ribov, Manol (1997). Konkurentsiya i konkurentosposobnost na turisticheskiya product. Sofia [in Bulgarian: Рибов, М., (1997): Конкуренция и конкурентоспособност на туристическия продукт, София. unwe.acad.bg/yearbook/2007/6.pdf

Saxena, G. (2016). Marketing Rural Tourism. doi:10.4337/9781784710880

Smith, V. L., \& Eadington, W. R. (1996). Tourism alternatives: Potentials and problems in the development of tourism. Chichester etc.: John Wiley \& Sons.

Sofield, T. H. (2006). Border Tourism and Border Communities: An Overview. Tourism Geographies, 8(2), 102121.

Stankova, M., \& Vasenska, I. (2015). Competitiveness and tourism development: In search of positive imagerepresentations of Bulgaria as a destination. Ekonomika, 61(3), 43-60. doi:10.5937/ekonomika1503043s

Stoykova, B. (2008). Contemporary tendencies in development of sacred tourism in Bulgaria. International Review on Public and Nonprofit Marketing, 6(1), 1-9. doi:10.1007/s12208-008-0020-7

Studzieniecki, T., \& Korneevets, V. (2016). The role of the European neighbourhood policy instrument in the tourist development of the Lithuanian - Polish - Russian Borderland. XIX. Mezinárodni Kolokvium O Regionálních Vèdách. Sborník Přspèvkeì. doi:10.5817/cz.muni.p210-8273-2016-146 
Terziyska, I. (2017). Benchmarking wine tourism destinations - the case of Bulgaria. International Journal of Wine Business Research, 29(4), 384-400. doi:10.1108/ijwbr-01-2017-0004

Verbole, A. (2000). Actors, Discourses and Interfaces of Rural Tourism Development at the Local Community Level in Slovenia: Social and Political Dimensions of the Rural Tourism Development Process. Journal of Sustainable Tourism, 8(6), 479-490.

Verbole, A., \& Cottrell, S. (2002). Rural tourism development: Case of a negotiating process in Slovenia. World Leisure Journal, 44(2), 21-28. doi:10.1080/04419057.2002.9674267

Xu, K., Zhang, J. \& Tian, F. (2017). Community leadership in rural tourism development. Sustainability, 9 , 23-44.

Wachowiak, H. (ed.) (2006). Tourism and Borders: Contemporary Issues, Policies, and International Research. Ashgate: Aldershot. 